\title{
PELATIHAN DAN PENDAMPINGAN APLIKASI PAYET PADA PRODUK KULIT KAYU NYAMU DAN ROTAN DI KELOMPOK PERAJIN
}

\author{
Yusintha Tanduh ${ }^{1}$, Nursiah ${ }^{2}$, Reni Rahmawati ${ }^{3}$, Zaki Yamani $^{4}$ \\ ${ }^{1,2,3,4}$ Fakultas Pertanian Universitas Palangka Raya \\ yusintha@for.upr.ac.id
}

\begin{abstract}
Nyamu and Rattan bark by the people of Central Kalimantan in general are only used for binding, making traditional clothes that are used in certain events only. Even though there are still many things that can be made from this Nyamu leather raw material, such as alternative materials for making longsongan bags, modified into bags or wallets which can then be further developed in terms of design. To increase the value of beauty and increase the value of handicraft products made from Nyamu bark such as bags and wallets, it is carried out by means of unified matching sequins as a way to enhance the appearance of the products produced and become a special feature of this Nyamu bark product. PKW which is motivated by the assistance of partners in empowering the community in this activity will provide Training and Assistance in the Black and White Craftsmen Group. The method used is active participatory community empowerment through collaboration with partners namely the transfer of knowledge and technology through training activities. All PKW activities went smoothly according to plan. The partner is able to practice what is involved in the activity and has already produced a bag and wallet product with modified sequins. Based on the results of monitoring and evaluation, around $70 \%$ of participants succeeded in sewing wallets and purses, while $90 \%$ of participants had already started to be skilled at making various patterns of sequin paintings, and several products were sold.
\end{abstract}

Keywords: Nyamu Bark, Rattan, Sequin, Craftsman.

\section{PENDAHULUAN}

Kulit kayu Nyamu dan Rotan merupakan Hasil Hutan Bukan Kayu (HHBK) yang banyak dimanfaatkan oleh masyarakat karena berbagai fungsi dan manfaatnya. Kulit Kayu Nyamu dibeberapa daerah dikenal dengan nama yang berbeda yaitu Lantung, Jomok, dan lain sebagainya. Kulit kayu ini oleh masyarakat Kalimantan Tengah pada umumnya hanya digunakan untuk pengikat, membuat baju adat yang digunakan pada event-event tertentu saja (ewah, sangkarut, lawung, salui tanjut, sangkirai, sumping). Padahal masih banyak yang dapat dibuat dari bahan baku kulit Nyamu dan Rotan ini, misalnya dijadikan alternatif bahan pembuatan tas longsongan dimodifikasi menjadi tas atau dompet yang kemudian dapat dikembangkan lagi dari segi desain yang tentunya disukai oleh kalangan masyarakat luas (Santie, 2015).

Lebih lanjut dijelaskan oleh Santi (2015) bahwa selain itu produk penuh dari kulit kayu Nyamu ini juga dapat dikombinasi dengan berbagai bahan kulit kayu lainnya. Adanya produksi tas atau dompet dengan bahan kulit kayu Nyamu dan Rotan yang dikombinasikan dengan bahan lainnya diharapkan dapat memberikan inovasi baru dan meningkatkan nilai ekonomis dari kulit kayu Nyamu dan Rotan.

Untuk menambah nilai keindahan dan menaikkan nilai produk hasil kerajinan dari kulit kayu Nyamu dan Rotan seperti tas dan dompet, kombinasi penambahan bahan dapat dilakukan dengan teknik padu padan payet sebagai cara untuk mempercantik tampilan produk yang dihasilkan dan menjadi ciri khusus di produk kulit kayu Nyamu ini. Payet merupakan benda kecil yang bisa memberi arti besar apabila diperlakukan dengan sentuhan (Maya dan Coly, 2007) dan dipadu pada produk kerajinan ataupun pakaian dengan gambar atau pola dari suatu budaya setempat.

Namun, dari hasil produk kulit kayu Nyamu dan Rotan yang selama ini digunakan oleh masyarakat di Kalimantan Tengah, belum ada pengembangan terhadap sentuhan 
kreasi pemberian padu padan payet, khususnya dalam pembuatan tas maupun dompet. Maka berdasarkan latar belakang itulah, penciptaan produk ini akan memanfaatkan kulit kayu Nyamu dan Rotan sebagai bahan utama dalam pembuatan tas dan dompet, dengan penambahan sentuhan padu padan payet, yang diharapkan dapat menambah keindahan, ke-elegen-an produk yang dihasilkan, sehingga nantinya akan diminati konsumen, harga jual cukup tinggi tanpa meninggalkan ke-khas-an asal produk.

Kelompok Perajin Hitam-Putih sebagai mitra, selama ini memproduksi lawung, sumping dan pakaian adat dari kulit kayu Nyamu dan Rotan. Permasalahan pertama yang terjadi pada mitra adalah produk ini digunakan hanya pada waktu-waktu tertentu dan tidak semua kalangan membutuhkannya. Produk lawung dan sumping tidak setiap hari dicari dan tidak setiap hari terjual, justru konsumen banyak mencari dompet dan tas. Permasalahan kedua adalah mitra belum mengetahui pengetahuan teknik pemasaran. PKW yang dilatarbelakangi oleh pendampingan mitra dalam memberdayakan masyarakat dalam kegiatan Pengabdian Kepada Masyarakat akan memberikan Pelatihan Dan Pendampingan Aplikasi Payet Pada Produk Kulit Kayu Nyamu Dan Rotan Di Kelompok Perajin Hitam Putih.

Solusi pertama yang akan diberikan dalam kegiatan PKW ini adalah memodifikasi dan menambah variasi produk, seperti membuat dompet dan tas padu-padan kulit kayu Nyamu dan Rotan dengan sentuhan payet, mengaplikasikan payet pada tas/dompet kulit kayu Nyamu, mengaplikasikan payet pada tas/dompet rotan. Solusi kedua memberikan pengetahuan tentang teknik pemasaran sehingga hasil kerajinan yang dihasilkan dikenal masyarakat luas dan hasil penjualan semakin meningkat.

\section{METODE}

Pada kegiatan PKW ini metode yang dilakukan adalah pemberian materi tentang kegiatan yang akan dilakukan. Agar dalam pemberian materi dapat diserap oleh peserta dengan mudah, maka dalam kegiatan ini digunakan metode sebagai berikut:

1. Metode ceramah dan tanya jawab untuk memperkenalkan pengetahuan dan keterampilan yang diberikan. Metode ceramah diberikan ketika memperkenalkan materi, tentang bahan-bahan dan alat yang dipakai serta langkah-angkah yang di lakukan dalam membuat tas dan dompet serta pembagian modul terkait pengembangan keterampilan dan teknologi. Selanjutnya dilakukan tanya jawab tentang materi yang telah dijelaskan. Tanya jawab juga berfungsi untuk mengetahui sejauh mana pemahaman peserta terhadap materi yang diberikan.

2. Metode demonstrasi diberikan dalam proses membuat tas dan dompet. Kepada peserta pelatihan didemonstrasikan bagaimana teknik membuat tas dari mendesain, memindahkan desain tas, membuat pola dompet dan tas, memindahkan pola ke masing-masing bahan, mengoles lem, memotong masing-masing bahan, memindahkan pola motif untuk di payet, memasang payet dan menjahit tas dan dompet sesuai tahapannya sampai finising.

3. Metode drill atau latihan yang diberikan kepada peserta, serta diiringi dengan bimbingan mulai dari cara mendesain memindahkan desain tas, Membuat pola dompet dan tas, Memindahkan pola ke masing-masing bahan, mengoles lem, memotong masing-masing bahan, memindahkan pola motif untuk di payet, memasang payet dan menjahit tas dan dompet sesuai tahapannya sampai finising. Kepada setiap peserta diberikan bahan dan peralatan menjahit. Setiap peserta dilatih dan dibimbing cara menggunting dan menjahit, sesuai dengan urutan kerja yang telah didemonstrasikan oleh pelatih. 
4. Metode pemberian tugas yang diberikan kepada peserta setelah pelatihan. Tugas dapat dikerjakan di rumah masing-masing, berdasarkan desain yang dibuat masing masing dan yang sudah di sempurnakan oleh pelatih dan tugas dibuat sesuai dengan teknik yang diberikan. Mitra diharapkan mampu menyelesaikan masing-masing produk (tas dan dompet).

5. Produk yang telah dihasilkan oleh mitra selanjutnya akan di pasarkan. Proses pemasaran dilakukan melalui penjualan secara online maupun penjualan secara langsung.

Dengan adanya kegiatan ini maka secara langsung dapat membuka lapangan pekerjaan baru di kelompok perajin sebagai mitra, menumbuhkan jiwa keterampilan mitra serta menambah pendapatan bagi anggota mitra tersebut. Keterlibatan mahasiswa dalam kegiatan Pengabdian Pada Masyarakat ini setidaknya membuka wawasan dan penerapan serta aplikasi tentang kewirausahaan sehingga jiwa usaha terbentuk.

Kegiatan PKW ini juga bekerjasama dengan Pemkot dalam hal ini adalah Dinas Perindustrian dan Perdagangan Kota Palangka Raya. Kontribusi yang diharapkan dari Pemkot terhadap kegiatan yang dilaksanakan adalah adanya Pembinaan dan Pendampingan kepada Mitra, untuk selanjutnya dapat diikutsertakan pada beberapa event sehingga produk bisa dikenal dan diminati pasar.

\section{HASIL KARYA UTAMA DAN PEMBAHASAN}

\section{Kegiatan Sosialisasi dan Penyuluhan}

Kegiatan penyuluhan dalam bentuk ceramah diberikan kepada peserta pelatihan dengan tujuan untuk memperkenalkan pengetahuan dan keterampilan yang diberikan. Metode ceramah diberikan ketika memperkenalkan materi, tentang bahan-bahan dan alat yang dipakai serta langkah-angkah yang di lakukan dalam membuat tas dan dompet. Sebelum kegiatan ceramah terlebih dahulu dilakukan kegiatan sosialisasi yang dihadiri oleh pihak Dinas Perdagangan dan Perindustrian Kota Palangka Raya, anggota kelompok Hitam Putih, mahasiswa dan tim pelaksana kegiatan. Pada kegiatan sosialisasi ini disampaikan maksud dan tujuan kegiatan yang merupakan tindak lanjut dari pertemuan awal dengan kelompok perajin Hitam Putih dan selanjutnya kegiatan akan dilaksanakan dalam bentuk pelatihan berupa praktek langsung tahapan aplikasi memasang payet pada tas dan dompet. Kegiatan utama Tim Pelaksana dari LPPM UPR bekerjasama dengan mitra Hitam Putih ini merupakan implementasi dari Tri Dharma Perguruan Tinggi yakni Pengabdian Pada Masyarakat.

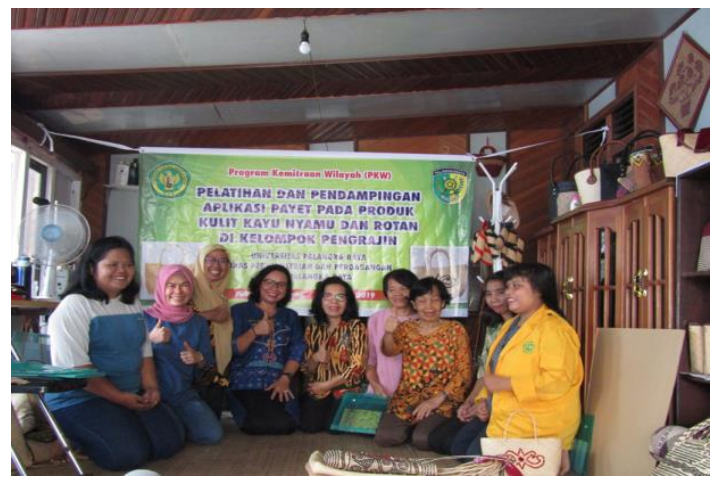

Gambar 1. Tim, Mitra dan Dinas Perdagangan dan Perindustrian Kota Palangka Raya

Arahan dan masukkan dari pihak Dinas Perdagangan dan Perindustrian Kota Palangka Raya sangat menginspirasi anggota kelompok untuk selalu semangat dalam 
berkarya mengembangkan bakat yang ada, demikian juga untuk mahasiswa yang ikut terlibat pada kegiatan ini. Selanjutnya dari pihak terkait, juga menawarkan program kerja mereka untuk memfasilitasi kegiatan pada masyarakat dengan menawarkan dan mempersilahkan mengajukan proposal bantuan tenaga pendamping dan pelatih.

\section{Kegiatan Pelatihan}

Setelah kegiatan sosialisasi dan ceramah, kemudian dilanjutkan dengan pelaksanaan pelatihan aplikasi payet pada produk kulit Nyamu dan rotan yang dilaksanakan sebanyak lima kali pertemuan dan jumlah peserta sebanyak lima orang. Pada pertemuan pertama ini sampai pada pertemuan kelima yang kegiatannya telah menghasilkan produk tas dan dompet yang berbahan kulit nyamu dan rotan dengan aplikasi payet sudah berhasil dilaksanakan dengan baik sesuai dengan rencana kegiatan. Kelompok perajin Hitam Putih sebagai mitra sangat antusias dalam mengikuti pelatihan dan menerima pendampingan yang dilakukan oleh tim kegiatan pengabdian di Kelurahan Bukit Tunggal. Hal ini terlihat dari partisipasi aktif peserta kelompok Hitam Putih dan mahasiswa saat kegiatan berlangsung baik dengan mengajukan pertanyaaanpertanyaan pada saat pelatihan dan langsung ikut mempraktekkan sesuai dengan materi yang sudah dijelaskan oleh tim PKW.

Urutan -urutan kegiatan pelatihan adalah sebagai berikut:

\section{a. Pelatihan Pertama}

Pada pelatihan pertama ini difokuskan mengenai pengenalan bahan-bahan payet dan teknik membuat pola tempat memasang payet serta teknik memasang payet tunggal, ganda dan tripel. Pada pelatihan pertama ini juga dijelaskan tentang alat dan bahan yang digunakan dan pengenalan mesin yang digunakan pada kegiatan pelatihan. Dokumentasinya tersaji pada Gambar 2, 3 dan 4.
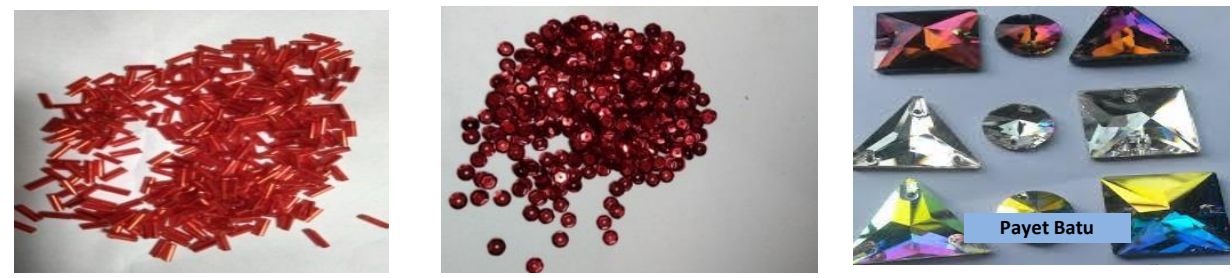

Gambar 2. Jenis-jenis payet yang digunakan pada kegiatan pelatihan
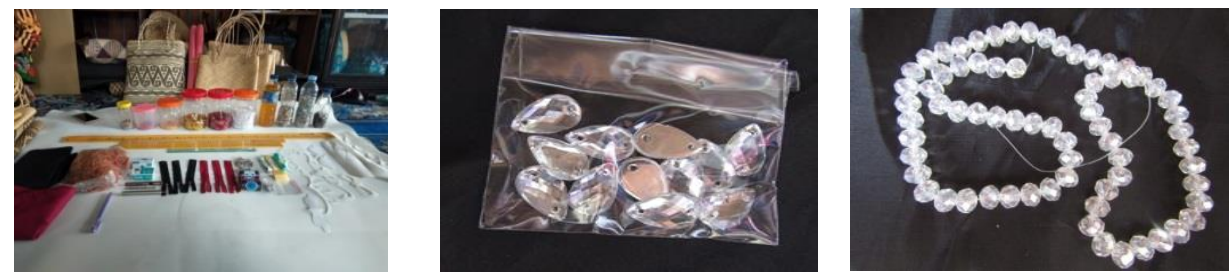

Gambar 3. Alat dan Bahan yang digunakan pada kegiatan pelatihan
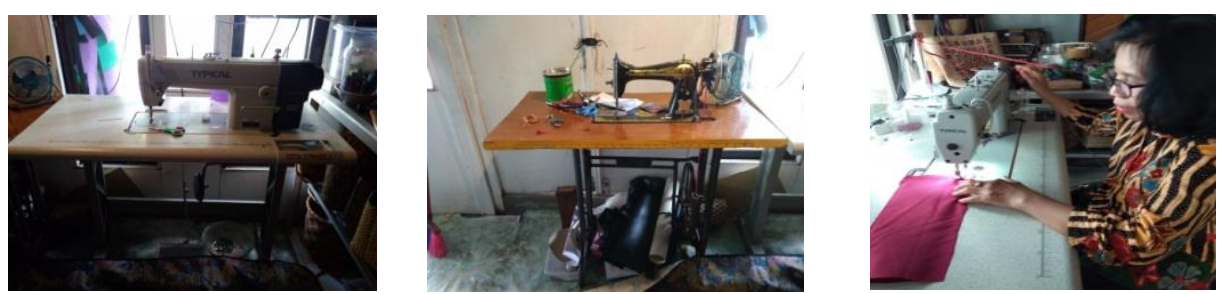

Gambar 4. Jenis mesin jahit yang digunakan saat kegiatan pelatihan 
Pada kegiatan ini diberikan penjelasan lengkap tentang payet sebagai bahan yang akan digunakan pada pelatihan. Payet biasanya digunakan untuk menghiasi aneka busana, tas maupun kain peralatan rumah tangga. Payet ada yang berjenis kilap dan ada pula yang tidak kilap. Hiasan payet umumnya digunakan bersamaan dengan manik-manik kecil yang di daerah Jawa disebut manik-manik pasir. Pelekatan payet pada kain haruslah menggunakan tangan. Sementara benang yang digunakan untuk menjahitnya dapat berupa sehelai benang maupun dua helai benang. Untuk melekatkan payet pada kain tipis dan halus, gunakan sehelai benang. Pada kain yang tebal, gunakan dua helai benang untuk memantapkan posisi hiasan payet. Kreasi hiasan payet sangat beragam. Mulai dari bentuk bunga, daun, sampai bentuk abstrak dapat dibuat. Kreasi bentuk hiasan payet yang indah tergantung dari kreativitas pemayet.

Setelah pengenalan jenis-jenis payet, alat dan bahan serta jenis mesin jahit yang digunakan pada saat kegiatan pelatihan, kemudian dilanjutkan dengan tutorial pembuatan pola lukisan payet. Dokumentasi kegiatan seperti yang terlihat pada Gambar 5.
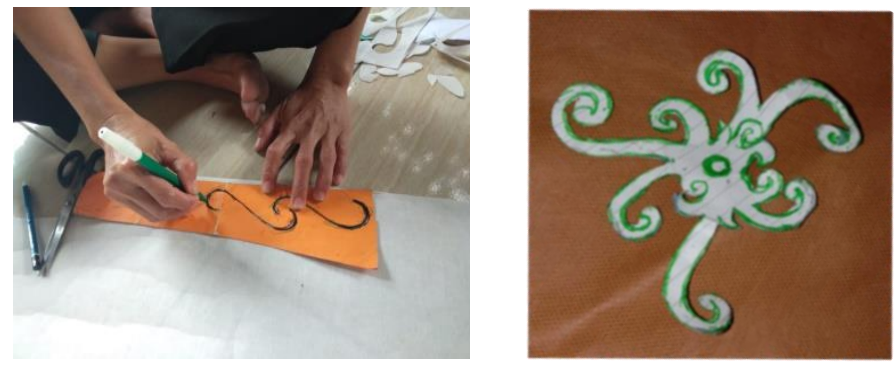

Gambar 5. Membuat Pola pada Kertas dan Folkrah

Dalam kegiatan menjahit, pembuatan pola merupakan kegiatan awal pada pekerjaan menjahit. Tujuan dari pembuatan pola diantaranya mempermudah pekerjaan menjahit, mengefektifkan pemakaian bahan dan menjadikan ketepatan bentuk. Pola dipersiapkan agar penjahit tidak mengalami kerugian bahan dan untuk menghemat waktu. Pola dijadikan acuan dalam memotong dan menjahit bahan/pakaian. Dengan dibuatnya pola diharapkan tingkat kerja dapat diminimalisir serta hasil jahitan dapat disesuaikan dengan ukuran yang diinginkan (Anonim, 2020). Setelah pembuatan pola lukisan payet dilanjutkan dengan memindahkan pola ke bahan anyaman rotan. Dokumentasi kegiatan tersaji pada Gambar 6.
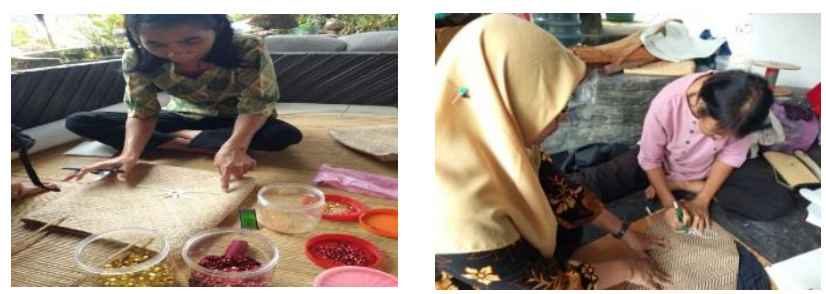

Gambar 6. Memindahkan Pola Payet Ke Bahan Anyaman

Pada kegiatan ini mitra diajari mulai dari memotong kain dengan pola sesuai ukuran yang dibutuhkan dibawah bimbingan oleh pelatih kegiatan. 


\section{b. Pelatihan Kedua}

Kegiatan pelatihan kedua adalah lanjutan dari kegiatan pelatihan pertama. Hasil dari kegiatan memindahkan pola payet ke bahan anyaman di pelatihan pertama dilanjutkan dengan proses memasang payet, baik itu payet tunggal (satu lapisan), ganda (dua lapisan) maupun tripel (tiga lapisan). Dokumentasi kegiatan seperti pada Gambar 7.
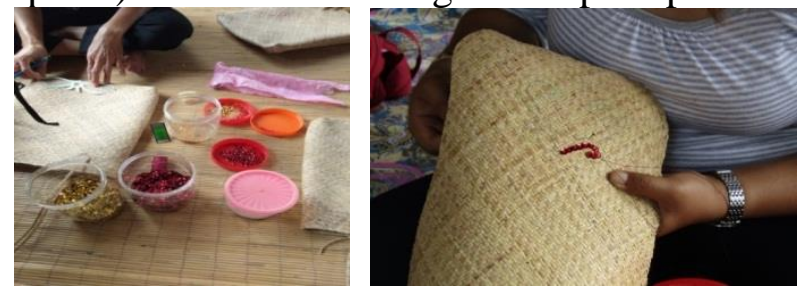

Gambar 7. Memasang payet pada tas yang sudah terbentuk

Kegiatan berikutnya pada pelatihan kedua ini adalah membuat pola tas, memotong pola, mengoles lem, dan merekatkan bahan. Pola tas dan dompet dibentuk sesuai ukuran tas yang diinginkan. Pola dibikin diatas lembaran spon selanjutnya dipotong dan masingmasing bahan, baik spon dan anyaman rotan di oles dengan lem dan direkatkan. Pada tahap ini bisa langsung dipasang payet ataupun tas dan dompetnya dijahit terlebih dahulu, dan selanjutnya baru dipasang payet. Dokumentasi kegiatan berturut-turut disajikan pada Gambar 8,9 dan 10.
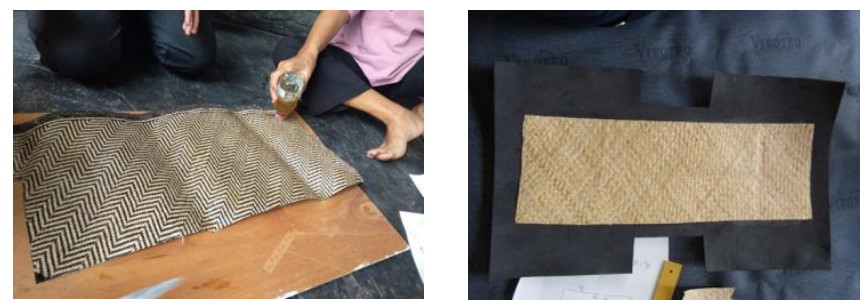

Gambar 8. Memindahkan dan memotong bahan
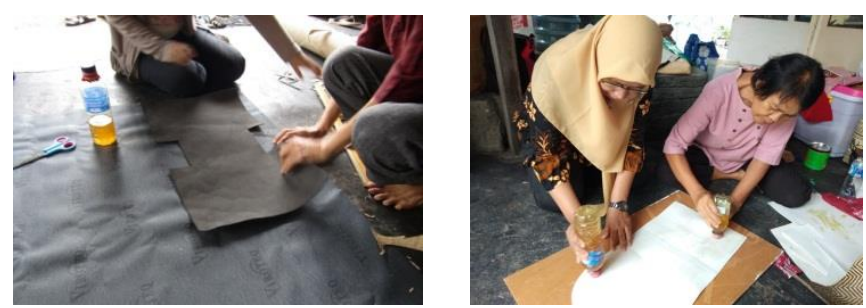

Gambar 9. Mengoles lem pada bahan
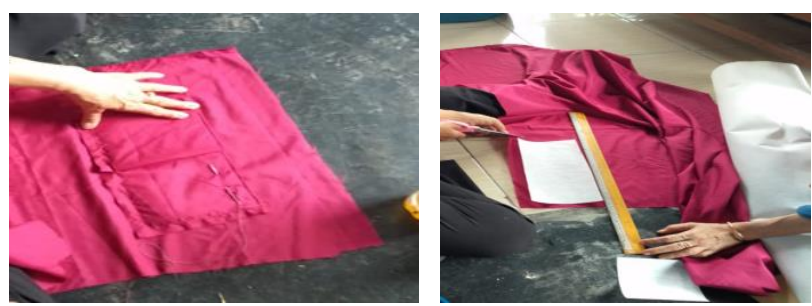

Gambar 10. Mengukur dan membuat lapisan dalam tas serta memasang kantong

Proses-proses kegiatan pelatihan yang dilakukan oleh kelompok perajin Hitam Putih sepenuhnya melalui bimbingan pelatih yang telah ditunjuk oleh tim PKW. Tahapantahapan dalam pelatihan kedua ini diikuti dengan antusias oleh kelompok perajin Hitam Putih, karena kegiatan ini merupakan kegiatan yang pertama kali dilakukan. 


\section{c. Pelatihan Ketiga}

Pada pelatihan ke tiga ini melanjutkan dan menyelesaikan pemasangan payet dan mulai menjahit tas dan dompet, serta menambah produk tas. Dokumentasi kegiatan seperti yang disajikan di Gambar 11, 12 dan 13.
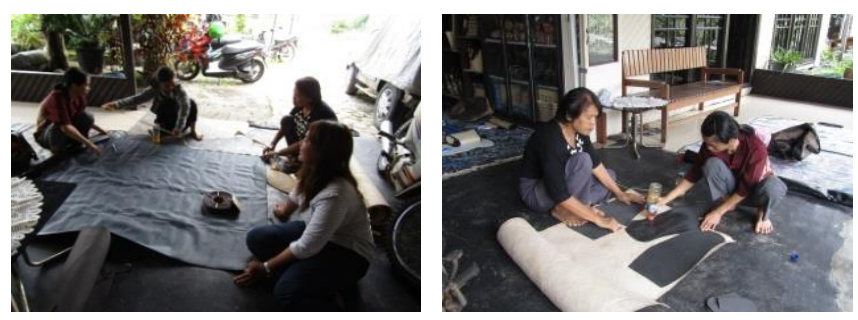

Gambar 11. Memotong tambahan tas desain baru
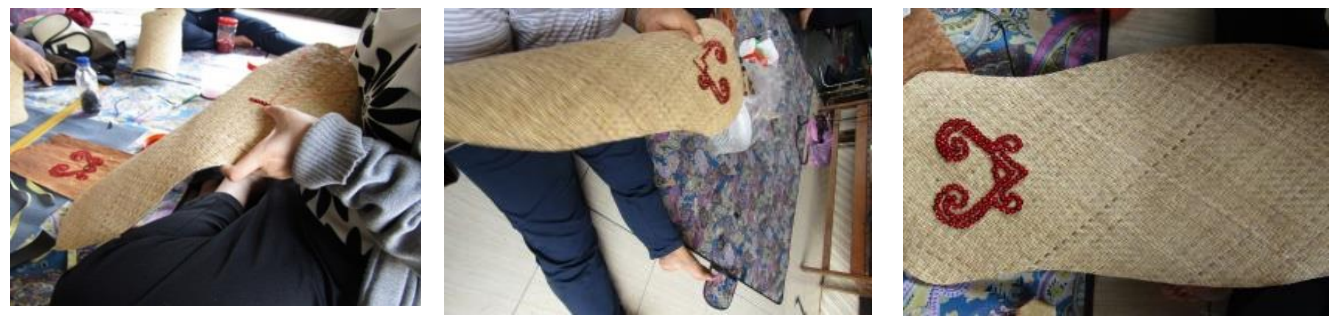

Gambar 12. Melanjutkan pemasangan payet dan hasil memayet
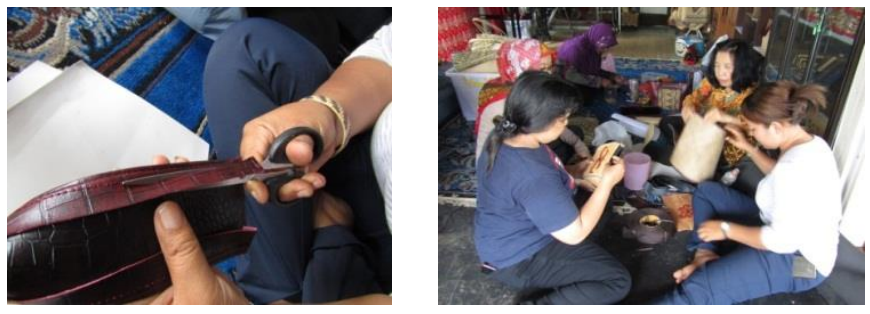

Gambar 13. Menggunting sisi dompet yang akan disatukan dan dililit

Kegiatan yang dilakukan pada pelatihan ketiga yakni proses menjahit bukanlah hal yang baru mereka lakukan, karena dalam kegiatan memproduksi lawung dan sejenisnya juga melalui proses menjahit bahan, yang pada akhirnya kegiatan pada pelatihan ke tiga ini dapat terlaksana tanpa kendala.

\section{d. Pelatihan Ke Empat}

Pelatihan ke empat merupakan kegiatan lanjutan yakni kegiatan menjahit lapisan dalam, pembuatan kantong, menyelesaikan menjahit tas dan dompet dari bahan rotan, memasang tali tas, asesories seperti keling, sepatu tas, kancing dompet dan memastikan semua bagian terpasang dengan baik. Dokumentasi kegiatan tersaji pada Gambar 14, 15 dan 16.
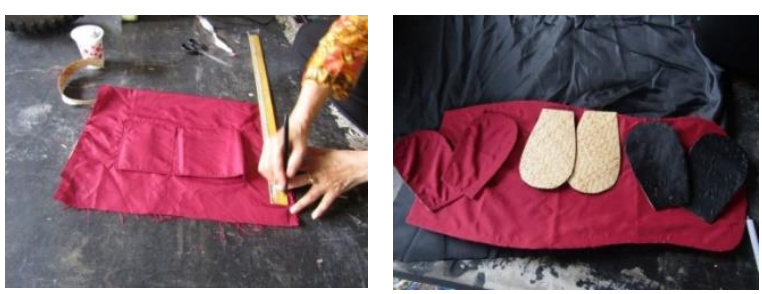

Gambar 14. Bentuk Kantong tas dan bagian-bagian yang akan dijahit 


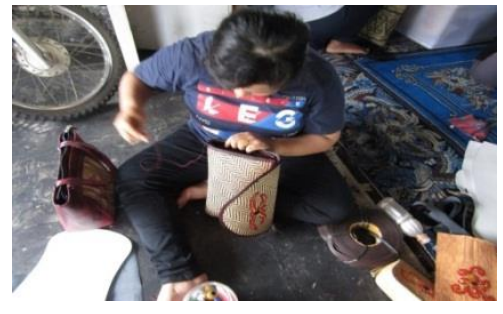

Gambar 15. Melilit dompet

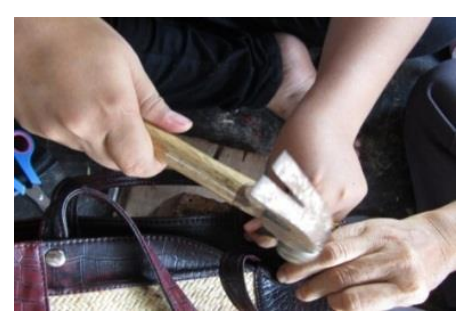

Gambar 16. Memasang tali Tas

Setelah para peserta pelatihan mengenal dan melakukan praktek langsung membuat tas dan dompet dan memasang payet, mereka akan diarahkan kepada pembuatan bermacam-macam pola/motif lukisan untuk memasang payet yang berorientasi pada usaha. Fokus hasil tas dan dompet yang sudah dipasang payet adalah bermacam jenis variasi sehingga pembeli banyak pilihan dan bentuk yang berbeda-beda atau dapat juga menjadikannya sebagai koleksi.

Kegiatan pada pelatihan ke empat adalah kegiatan terakhir dari proses pembuatan tas dan dompet dan penambahan payet pada tas dan dompet yang dihasilkan. Namun, kegiatan pelatihan ini belum berakhir dan masih akan dilanjutkan pada kegiatan pelatihan ke lima.

\section{e. Pelatihan Ke Lima}

Pelatihan kelima memastikan semua bagian terpasang dengan baik dan mengakhiri semua kegiatan bersama mitra. Kegiatan pada pelatihan ke lima ini adalah kegiatan monitoring dan evaluasi dilakukan sementara kegiatan pelatihan sedang berlangsung guna memastikan kesesuaian proses dan capaian sesuai dengan tujuan utama kegiatan ini atau tidak. Dari hasil monitoring dan evaluasi pada tahap-tahap kegiatan diketahui tidak terdapat kendala yang berarti sehingga peserta pelatihan sangat optimis kegiatan ini dapat berlanjut secara mandiri tanpa pendampingan dari tim pelaksana. Berikut dokumentasi tas dan dompet dari hasil karya mitra yakni perajin Hitam Putih.
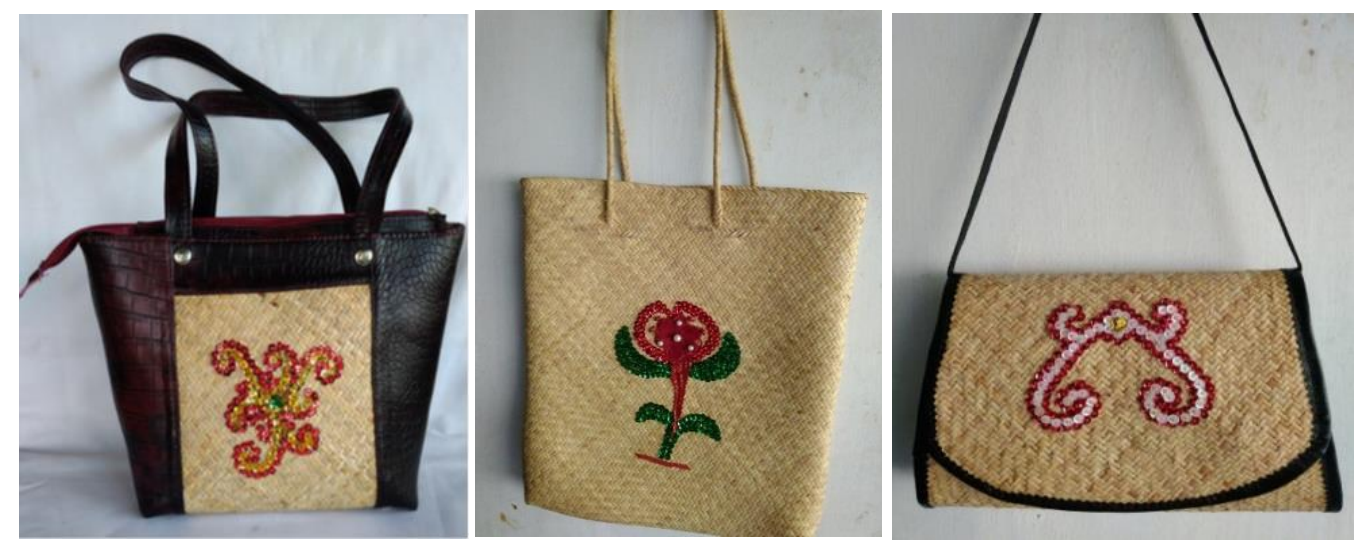

Gambar 22. Hasil-hasil pelatihan produk Tas 


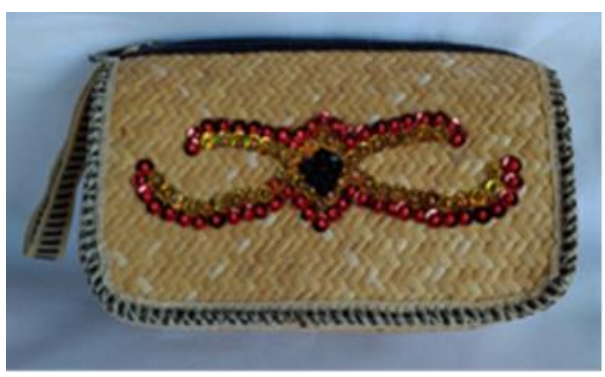

(a)

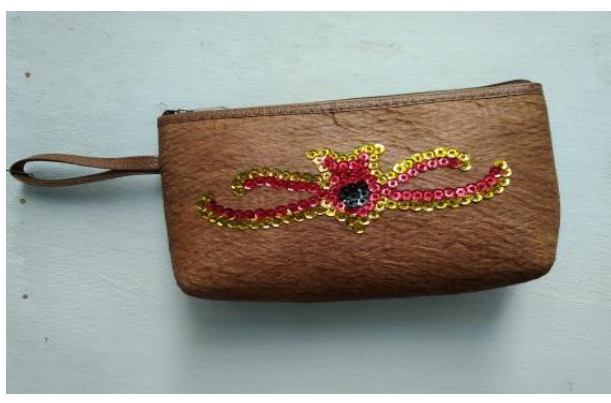

(c)

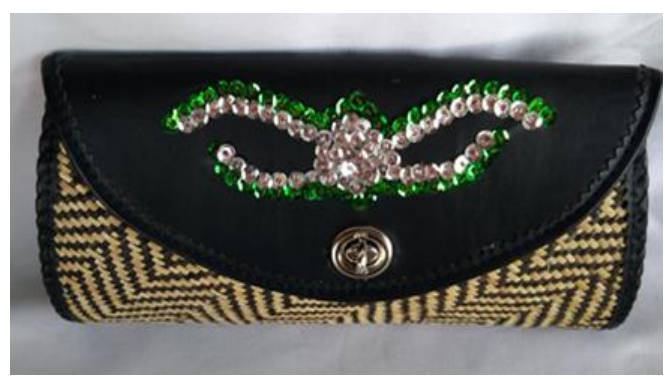

(b)

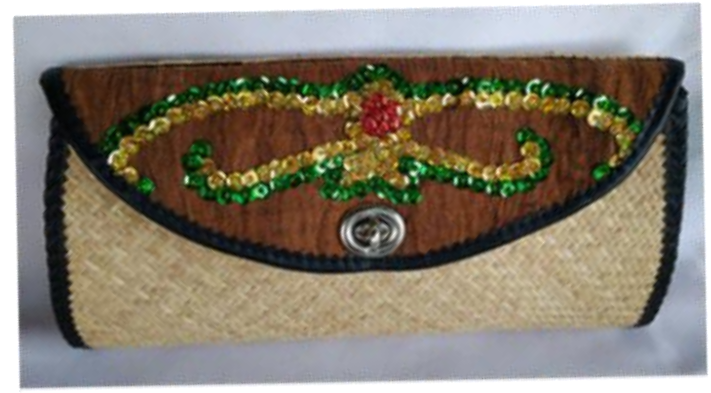

(d)

Gambar 23. Hasil-hasil pelatihan produk dompet rotan kombinasi vinil (a) Rotan, (b) Rotan kombinasi vinil, (c) Kulit kayu Nyamu, (d) Rotan kombinasi kulit kayu Nyamu

Pada kegiatan pelatihan ke lima ini juga diberikan pelatihan tentang pemasaran produk yang diberikan dengan tujuan agar peserta tidak hanya dapat membuat produk, tetapi juga mampu mendistribusikan memasarkan produknya sendiri. Pada pelatihan ini dijelaskan bahwa kreatifitas dan kemampuan seorang marketing dalam memasarkan produk juga menentukan bagaimana cara menarik perhatian calon konsumen. Kemampuan ini sangat dipengaruhi oleh tingkat pengetahuan kita atau penguasaan kita pada produk yang kita jual dan kemampuan ini sangat dipengaruhi oleh faktor latihan atau kebiasaan (Dharmmesta et al. 1982). Semakin sering seorang marketing melakukan penerangan dan penjualan kepada orang lain, semakin bagus juga kemampuannya untuk menjual dan menguasai produk (Hendry et al. 2012). Berikutnya adalah hal tersulit dalam dunia marketing, yaitu membuat seorang pembeli menjadi pelanggan, alias mau kembali terus menerus membeli produk milik kita. Tahap terakhir ini berhubungan dengan banyak hal. 1. Kualitas produk yang kita tawarkan 2. Pelayanan yang kita berikan 3. Pola komunikasi yang kita bangun dengan konsumen (Kotler, 1999).

Berdasarkan hasil monitoring dan evaluasi sebanyak 2 kali setelah kegiatan pelatihan selesai dilaksanakan ternyata peserta sekitar $70 \%$ telah berhasil melakukan proses menjahit tas dan dompet berdasarkan keterampilan yang diperoleh pada saat pelatihan, sedangkan untuk memasang payet sudah mencapai $90 \%$ peserta sudah mulai mahir membuatnya. Peserta sudah mulai memproduksi hasil dari pelatihan tersebut yakni produk tas dan dompet dengan modifikasi payet dan sudah terjual.

\section{KESIMPULAN}

Pelatihan ini sangat membantu kelompok perajin Hitam Putih dalam mengembangkan kreatifitas dan inovasinya untuk menghasilkan produk yang lebih bervariasi sehingga nilai jual anyaman rotan dan kulit kayu Nyamu akan bernilai jual 
lebih tinggi. Semua kegiatan pelatihan berjalan lancar sesuai dengan rencana dan peserta pelatihan sangat antusias dan semangat dalam mengikuti pelatihan tersebut. Peserta pelatihan sudah memahami dan sudah mempraktekkannya yang sudah didapatkan pada pelatihan yang telah dilakukan. Berbagai macam kreativitas dan inovasi dapat dilakukan untuk menghasilkan suatu produk, seperti tas longsongan dimodifikasi menjadi tas yang ada sentuhan payet atau lembaran tikar dibentuk mejadi tas atau dompet padu-padan bahan dengan sentuhan payet. Peserta sudah mulai memproduksi hasil dari pelatihan tersebut dan beberapa produk tas dan dompet dengan modifikasi payet sudah terjual.

\section{UCAPAN TERIMA KASIH}

Ucapan terima kasih disampaikan kepada Universitas Palangka Raya khususnya Lembaga Penelitian dan Pengabdian Kepada Masyarakat UPR yang telah memberikan alokasi dana melalui DIPA PNBP Universitas Palangka Raya Tahun 2019 untuk pelaksanaan kegiatan ini. Selain itu, ucapan terima kasih juga disampaikan kepada kelompok mitra perajin di Kelurahan Bukit Tunggal yang sangat membantu dalam terlaksananya kegiatan ini.

\section{DAFTAR PUSTAKA}

Anonim. 2020. Pola Pakaian, melalui https://fitinline.com/article/read/pola-pakaian diakses pada 17 Mei 2020.

Dharmmesta, B.S., Handoko, H. 1982. Manajemen Pemasaran: Analisis Perilaku Konsumen. Yogyakarta: PBFE Universitas Gajah Mada.

Hendry, H., Hutomo, K., Mayangsari, M. 2012. Pengaruh Strategi Pemasaran Terhadap Peningkatan Penjualan Pada Perusahaan Dengan Menetapkan Alumni Dan Mahasiswa Universitas Bina Nusantara Sebagai Objek Penelitian. Binus Business Review Vol. 3 No. 2 November 2012: 882-897

Januminro. 2000. Rotan Indonesia: Potensi, Budi Daya, Pemungutan, Pengolahan, Standar Mutu, dan Prospek Pengusahaan.Penerbit Kanisius, Yogyakarta.

Jawet Bawi. 2000. Macam-macam motif dare dan Silip. Koperasi Anyaman Rotan Jawet Bawi. Palangka Raya Kalimantan Tengah.

Kotler, Philip 1999. Marketing. terjemah oleh Purwoko M.A Herujati, Jilid 1, Jakarta: Erlangga.

Marizar, E.S. 2007. Rotan dan Material Unik. Serial Rumah - Furniture. PT. Gramedia. Jakarta

Maya dan Coly, 2007, Kreasi Sulam Payet Untuk Pemula. Jakarta : PT. Kawan Pustaka.

Santie. 2015. Analisa Ekonomi Pengrajin Kulit Nyamu di Kelurahan Palangka Kota Palangka Raya. 